\title{
TINGKAT PEMAHAMAN CALON GURU TERHADAP REVISI KURIKULUM 2013
}

\author{
Mujahidil Mustaqim \\ Program Studi Pengembangan Kurikulum, Universitas Pendidikan Indonesia \\ J1. Setiabudhi No.229, Isola, Sukasari, Isola, Sukasari, \\ Kota Bandung, Jawa Barat 40154 \\ Email: mujahidil.mustaqim@student.upi.edu \\ DOI: $10.29313 /$ tjpi.v6i2.4631
}

Accepted: January 6th, 2018. Approved: January 28th, 2018. Published: January 28th, 2018

\begin{abstract}
This article is based on the preliminary findings in the field that prospective teachers or students of practical field experience (PPL) are not comprehensively mastered therevised 2013 curriculum. This is reflected in the following matters: (a) Students of PPL initially and truly learn the essence of the revised curriculum during the PPL and not at the time of micro teaching lectures in the class. (b) Higher education does not provide a full 2013 curriculum concept so that students of PPL assessed having no adequate provisions to implement the revised curriculum. (c) The curriculum is quite often changed in a decade which complicate theteacher's candicates to understand the essence of curriculum differences from time to time. (d) Students of PPL often confused due to the gaps in understanding the 2013 curriculum whichthey studied theoretically in college compared to the practical in the field (e) other confusion is there are several schools and a number of teachers who have not been entirely accepted the concept of curriculum offered. Thus, this article reveals the following three points: First, the level of understanding of teacher's candidates to the revised curriculum of 2013 was 69.1\%. Second, the level of understanding of teacher's candidatesin the implementation of the revised curriculum of 2013 amounted to $57.5 \%$. Third, the level of understanding of teacher's candidatesto the evaluation of revised curriculum amounted to $13.6 \%$. Fourth, the level of understanding of teacher's candidates torevised curriculum as a whole includes an understanding of planning, implementation, and evaluation is $49.6 \%$.
\end{abstract}

Keywords: Revised Curriculum 2013, Practice Field Experience, and Teacher's Candicates.

\section{ABSTRAK}

Artikel ini didasari atas temuan sementara di lapangan bahwa calon guru atau mahasiswa praktek pengalaman lapangan (PPL) tidak menguasai secara komprehensif revisi kurikulum 2013. Ini tergambar dari hal-hal berikut: (a) Mahasiswa PPL betul-betul baru belajar esensi revisi kurikulum 2013 ketika sudah melakukan PPL bukan pada saat tatap muka perkuliahan terutama micro teaching. (b)Perguruan Tinggi tidak membekali konsep kurikulum 2013 secara penub sebingga mahasiswa PPL dinilai tidak mempunyai bekal yang cukup untuk mengimplenetasikan revisi kurikulum 2013 di sekolah. (c) Kurikulum yang cukup sering berubah dalam satu dekade menyulitkan calon guru dalam memahami esensi perbedaan kurikulum dari waktu ke waktu. (d) Seringkali mahasiswa PPL mengalami kebingungan karena ada kesenjangan pemahaman kurikulum 2013 yang dipelajari secara teoritis di perguruan tinggi dengan praktis di lapangan (e) Kebingungan lainnya adalah ada beberapa sekolah dan sejumlah guru yang belum sepenuhnya well come dengan konsep kurikulum yang ditawarkan. Dengan demikian, artikel ini mengungkap tiga hal berikut: Pertama, tingkat pemahaman calon guru terhadap revisi kurikulum 2013 adalah sebesar 69,1\%. Kedua, tingkat pemahaman calon guru terhadap implementasi revisi kurikulum 2013 adalah sebesar $57.5 \%$. Ketiga, tingkat pemahaman calon guru terhadap evaluasi revisi kurikulum 2013 adalah sebesar 13.6\%. Keempat, tingkat pemahaman calon guru terhadap revisi kurikulum 2013 secara keseluruban meliputi pemahaman perencanaan, implementasi dan evaluasi adalah sebesar 49,6\%.

Kata Kunci: Revisi Kurikulum 2013, Praktek Pengalaman Lapangan, dan Profesionalitas Guru. 


\section{PENDAHULUAN}

Perguruan tinggi dipandang sebagai organisasi professional berbasis pengetahuan dimana kepakaran dan penguasaan keilmuaan menjadi kompetensi SDM utama secara lansung melakukan upaya-upaya dalam proses pendidikan tinggi sehingga mutu lulusan sebagai dampak proses akan ditentukan oleh mutu SDM dalam mengembangkan profesionalitas dan ilmu pengetahuan (Uhar Suharsaputra, 2015: 65). Perguruan tinggi yang bertipe Lembaga Pendidikan Tenaga Keguruan (LPTK) yang memproduksi tenaga pendidik mempunyai tanggungjawab menghasilkan SDM yang berkualitas.

Dalam menyonsong pasar bebas global, untuk mencetak SDM yang bermutu tinggi maka merujuk pada Peraturan Presiden Nomor 08 Tahun 2012 terbit Kerangka Kualifikasi Nasional Indonesia (KKNI). KKNI adalah kerangka penjenjangan kualifikasi kompetensi yang dapat menyandingkan, menyetarakan, dan mengintegrasikan antara bidang pendidikan dan bidang pelatihan kerja serta pengalaman kerja dalam rangka pemberian pengakuan kompetensi kerja sesuai dengan struktur pekerjaan di berbagai sector (Direktorat Jenderal Pendidikan Tinggi Kementerian Pendidikan Nasional Republik Indonesia, 2007).

KKNI yang telah dirancang semenjak tahun 2003 melalui UU SISDIKNAS No 20 Tahun 2003 dan UU No 30 tentang ketenagakerjaan bertujuan untuk: a) menetapkan kualifikasi capaian pembelajaran yang diperoleh melalui pendidikan formal, nonformal, informal, pelatihan atau pengalaman kerja; 2) menetapkan skema pengakuan kualifikasi capaian pembelajaran yang diperoleh melalui pendidikan formal, nonformal, informal, pelatihan atau pengalaman kerja; 3) menyetarakan kualifikasi antara capaian pembelajaran yang diperoleh melalui pendidikan formal, nonformal, informal, pelatihan atau pengalaman kerja; dan 4) mengembangkan metode dan sistem pengakuan kualifikasi sumberdaya manusia dari negara lain yang akan bekerja di Indonesia.

Melalui KKNI, pemerintah ingin meningkatkan tingkat sumber daya manusia yang mampu bersaing tidak hanya dalam skala local ataupun nasional akan tetapi juga dapat setara dengan kualitas SDM internasional. Tidak terkecuali tenaga kerja pendidik. Apalagi, pendidik sebagai aktor utama dalam sustainability pendidikan bangsa tentu sangat diharapkan mempunyai kualifikasi dan profesionalitas yang mumpuni dalam mencetak benih-benih baru bangsa. Sebab logika yang dimainkan adalah semakin tinggi tingkat kualitas SDM pendidik maka akan semakin tinggi kualitas anak-anak bangsa. Lebih dari itu, pendidik dibandingkan jenis profesi lainnya meskipun dari sejumlah pandangan masih dicap "prestise" yang di bawah dan biasabiasa saja namun sumbangsihnya tentu akan selalu bermanfaat besar. Karena pendidik adalah tulang punggung pendidikan suatu bangsa dan bangsa-bangsa besar telah membuktikan itu.

Dalam kaitannya dengan KKNI, perguruan tinggi dikategorikan sebagai LPTK mempunyai kewajiban memproduksi calon guru yang sesuai dengan standar nasional dan setara dengan internasional. Secara umum ada dua fungsi LPTK yaitu : Pertama, LPTK yang fungsinya hanya menyelenggarakan pendidikan prajabatan, dan kedua adalah LPTK yang hanya menyelenggarakan pendidikan dalam jabatan (Natawidjaya, 1992). Lebih lanjut Natawidjaja (1983) menyebutkan ada LPTK yang bertugas menghasilkan guru TK, SD, SMP, SMA. Dan ada LPTK yang khusus bertugas menyediakan guru untuk jenis sekolah tertentu atau bidang studi misalnya guru pendidikan luar biasa atau guru olahraga kesehatan. Dengan kata lain tugas pokok LPTK adalah menyelenggarakan pendidikan untuk calon tenaga kependidikan untuk semua jenjang pendidikan serta keahliannya. Dari tujuan 
umum di atas, dirinci tujuan secara khusus yang bersifat operasional, yaitu: a). Menghasilkan guru SD, SMP dan SMA yang bermutu dan meliputi berbagai bidang studi sesuai dengan kebutuhan. 2). Menghasilkan tenaga kependidikan lain yang menunjang berfungsinya sistem pendidikan, seperti petugas administrasi pendidikan, petugas bimbingan dan konseling, pengembang kurikulum dan teknologi pendidikan, petugas pendidikan luar sekolah, dan lainlain sesuai dengan ketentuan system; 3). Menghasilkan tenaga ahli pendidik dalam membagi bidang studi, yang mampu memenuhi kebutuhan tenaga pendidik/instruktur bagi lembaga pendidikan pemerintah maupun swasta; 4). Menghasilkan ilmuan/peneliti dalam ilmu pendidikan baik bidang studi maupun bidang pendidikan lainnya. 5) Mengembangkan ilmu, teknologi dan seni kependidikan untuk menunjang praktek profesional kependidikan.

Mempersiapkan dan membina tenaga akademik untuk LPTK, sesuai dengan kebutuhan. 7) Mengembangkan dan melaksanakan program pendidikan dalam jabatan (in-service) untuk tenaga kependidikan. 8) Melayani usaha perbaikan dan pengembangan aparat pengelola pendidikan sesuai dengan pengembangan ilmu, metodologi dan teknologi serta seni kependidikan. 9) Melaksanakan penelitian dalam bidang kependidikan, baik pendidikan formal maupun pendidikan nonformal dan informal. 10) Melaksanakan program pengabdian pada masyarakat, yang berhubungan dengan masalah-masalah kependidikan (Natawidjaya, 1993).

Dalam mewujudkan tujuan LPTK tentu ada sekelumit persoalan yang meradang. Ada dua permasalahan pokok pada pendidikan calon guru di LPTK. Pertama adalah banyaknya jumlah LPTK dan yang kedua adalah rendahnya mutu LPTK yang merupakan wahana untuk meningkatkan tenaga pendidik (dalam Permenristekdikti No 13 Tahun 2015 tentang Rencana Strategis Kementerian
Riset, Teknologi, Dan Pendidikan Tinggi Tahun 2015-2019).

Untuk mewujudkan tujuan LPTK maka ada sejumlah upaya yang dilakukan secara tersistem diantaranya merancang kurikulum pembelajaran. Calon guru profesional seyogyanya dibekali untuk memiliki empat komponan utama kompetensi meliputi sosial, kepribadian, pedagogik dan professional. Upaya membentuk kompetensi ini tidak hanya bagian dari penguasaan keilmuan semata namun bagian upaya keahlian terapan. Karena menjadi seorang guru berarti paham akan konten yang akan diajarkan dan ahli dalam menyampaikan konten yang disampaikan.

Keahlian terapan calon guru salah satunya dibentuk melalui mata kuliah micro teaching dan program Praktek Pengalaman Lapangan (PPL). Para calon guru harus mendapatkan bekal yang memadai agar dapat menguasai sejumlah kompetensi yang diharapkan tersebut, baik melalui preservice training maupun inservice training. Salah satu bentuk preservice training calon guru tersebut adalah melalui pembentukan kemampuan dasar mengajar (teaching skill) baik secara teoritis maupun praktis. Secara praktis, bekal kemampuan mengajar dapat dilatihkan melalui kegiatan micro teaching atau pengajaran mikro (Tim Penyusun Buku Panduan Pengajaran mikro UNY, 2011: 1).

Sukirman (2005:189) mengatakan micro teaching adalah sebuah pembelajaran dengan salah satu pendekatan atau cara untuk melatih penampilan mengajar yang dilakukan secara "micro" atau disederhanakan. Penyederhanaan disini terkait dengan setiap komponen pembelajaran, misalnya dari segi waktu, materi, jumlah siswa, jenis keterampilan dasar mengajar yang dilatihkan, penggunaan metode dan media pembelajaran, dan unsur-unsur pembelajaran lainnya. Selanjutnya Hamalik (2009:144) mengatakan pengajaran mikro merupakan teknik baru dan menjadi bagian dalam pembaruan. Penggunaan pengajaran mikro dalam rangka 
mengembangkan keterampilan mengajar calon guru atau sebagai usaha peningkatan, adalah suatu cara baru terutama dalam sistem pendidikan guru di negera kita. Sedangkan Sardiman (2005:189) mengatakan micro teaching adalah meningkatkan performance yang menyangkut keterampilan dalam mengajar atau latihan mengelola interaksi belajar mengajar.

Bagi calon guru, micro teaching bertujuan antara lain: Pertama, memberikan pengalaman belajar yang nyata dan latihan sejumlah keterampilan dasar mengajar secara terpisah. Kedua, calon guru dapat mengembangkan keterampilan mengajarnya sebelum mereka terjun ke kelas yang sebenarnya. Ketiga, memberikan kemungkinan bagi calon guru untuk mendapatkan bermacam-macam keterampilan dasar mengajar serta memahami kapan dan bagaimana keterampilan itu diterapkan (dalam J.J. Hasibuan dan Moedjiono, 2009:46).

Tujuan PPL menurut Pedoman Program Pengalaman Lapangan (PPL) Universitas Pendidikan Indonesia (2016:2) bertujuan: 1) Tujuan Umum Agar para mahasiswa (praktikan) mendapatkan pengalaman kependidikan secara faktual di lapangan dan sebagai wahana untuk mempersiapkan tenaga pendidik dan kependidikan yang profesional. Pengalaman yang dimaksud meliputi pengetahuan, sikap, dan keterampilan dalam profesi sebagai pendidik, serta mampu menerapkannya dalam penyelenggaraan pendidikan dan pengajaran, baik di sekolah maupun di luar sekolah dengan penuh tanggung jawab; dan 2) Tujuan Khusus, a) Mengenal secara cermat lingkungan sekolah/tempat latihan dalam hal akademik, sosial, fisik, dan administrasi; b) Dapat menerapkan berbagai pengetahuan dan keterampilan dasar keguruan/kependidikan secara utuh dan terpadu dalam situasi sebenarnya; c) Memperoleh pengalaman mengajar dalam situasi nyata di sekolah; dan d) Mengintegrasikan berbagai pengalaman belajar dan penghayatan dalam upaya pencapaian keutuhan kompetensi akademik sebagaimana yang telah ditetapkan oleh program studi masing-masing.

Dengan demikian, adanya mata kuliah micro teaching dan PPL hendaknya dapat membentuk kompetensi calon guru utuh baik keilmuan dan keahlian terapan. Sebagaimana yang diungkapkan Beckman (dalam Uhar Suharsaputra, 2015: 183) bahwa pengetahuan yang utuh meliputi 5 hal berikut: a) Data, b) Information, c) Knowledge, d) Expertise; dan e) Capability.

Namun demikian, upaya memberi bakal yang komprehensif pada calon guru berupa pengoptimalan pembentukan kompetensi calon guru di perguruan tinggi dinilai tidak optimal salah satunya persoalan yang dikaji adalah tingkat pemahaman calon guru yang rendah terhadap kurikulum 2013. Ini merujuk hasil temuan sementera di lapangan menyebutkan sebagai berikut: 1). Mahasiswa PPL tidak menguasai secara komprehensif tentang kurikulum 2013 sebelum mengajar. Ini dapat dilihat dari halhal berikut: a) Mahasiswa PPL betul-betul baru belajar esensi kurikulum 2013 ketika sudah melakukan PPL bukan pada saat tatap muka perkuliahan terutama micro teaching, b) Perguruan Tinggi tidak membekali konsep kurikulum 2013 secara penuh sehingga mahasiswa PPL dinilai tidak mempunyai bekal yang cukup untuk mengimplenetasikan kurikulum 2013 di sekolah; c) Kurikulum yang cukup sering berubah dalam satu dekade menyulitkan calon guru dalam memahami esensi perbedaan kurikulum dari waktu ke waktu; dan d) Seringkali mahasiswa PPL mengalami kebingungan karena ada kesenjangan pemahaman kurikulum 2013 yang dipelajari secara teoritis di perguruan tinggi dengan praktis di lapangan

Kebingungan lainnya adalah ada beberapa sekolah dan sejumlah guru yang belum sepenuhnya well come dengan konsep kurikulum yang ditawarkan.

Pemahaman tentang kurikulum yang belum mendalam dan terkesan masih 
"meraba-raba" membuat mahasiswa PPL sering tidak leluasa dalam mengembangkan kompetensi diri dalam mengajar. Padahal kurikulum memegang peran sentral dalam pembelajaran. kurikulum bilamana diartikan sebagai sebuah perencanaan pembelajaran maka kurikulum ibarat pondasi dalam membangun sebuah rumah. Jika pondasinya kokoh dan didesain dengan rapi, maka sebuah rumah nantinya akan tahan terhadap goncangan. Begitu juga sebaliknya. Maka pondasi haruslah dibangun sebaik mungkin supaya rumah tersebut dapat bertahan dalam kondisi apapun.

Kurikulum sebagai pondasi, maka harus direncanakan sedini mungkin agar kesan yang timbul kurikulum tidak muncul secara tiba-tiba akan tetapi sudah melalui sejumlah prosedur yang matang dan kajian yang mendalam. Alhasil, kurikulum yang ditawarkan merupakan hasil olah pikir yangditelaahsecara tidak tergesa-gesa dan dengan hati-hati. Karena hakikatnya adalah keberhasilan pembelajaran nantinya sangat tergantung kurikulum yang didesain. Hal ini lebih detail tertera pada konsep kurikulum sebagai substansi sebagai berikut:

Kurikulum sebagai suatu substansi. Kurikulum dipandang sebagai suatu rencana kegiatan belajar bagi murid-murid di sekolah, atau sebagai suatu perangkat tujuan ingin dicapai. Suatu kurikulum juga dapat menunjuk kepada suatu dokumen yang berisi rumusan tentang tujuan, bahan ajar, kegiatan belajar-mengajar, jadwal, dan evaluasi. Suatu kurikulum juga dapat digambarkan sebagai dokumen tertulis sebagai hasil persetujuan bersama antara para penyusun kurikulum dan pemegang kebijaksanaan pendidikan dengan masyarakat. Suatu kurikulum juga dapat menmencakup lingkup tertentu, suatu sekolah, suatu kabupaten, propinsi, ataupun seluruh negara (Nana Syaodih, 2010: 27).

Kurikulum dapat dianalogikan sebagai draft acara. Misalnya, kita mengadakan sebuah kegiatan, maka pasti ada yang namanya draft acara yang disusun dari hasil diskusi bersama. Draft acara ini merupakan pedoman dalam melaksanakan sebuah acara. Baik buruk jalannya sebuah acara, tergantung dari draft acara yang didesain. Kurikulum dianalogikan sebagai draft pembelajaran memberi arahan implementasi kurikulum itu sendiri agar implementasinya sesuai dengan draft yang telah dirancang bersama. Pengalaman empirik pribadi di lapangan berkata bahwa sebaik-baik perencanaan yang telah dilakukan, masih ditemukan juga beberapa kelemahan. Apalagi, perencanaan yang dilakukan dengan tidak matang dan tergesagesa. Pada tahap selanjutnya, kurikulum berperan menjadi tolak ukur dalam menentukan seberapa jauh keberhasilan kurikulum yang telah dirancang. Dalam bahasa yang lebih sederhana, kurikulum yang adalah patokan untuk mengukur ketercapaian tujuan pembelajaran. Dalam buku "Kurikulum dan Pemikiran Pendidikan" menjelaskan sebagai berikut:

"Posisi sentral kurikulum dalam proses pendidikan dapat juga dilihat dari posisi kurikulum dalam mewujudkan tujuan-tujuan pendidikan. Dalam posisi ini, kurikulum disebut sebagai "kontrak kerja" untuk transaksi pendidikan yang berlansung di ruangan kelas. Kurikulum diibaratkan sebagai sebuah kendaraan yang dirancang untuk mencapai suatu tujuan. Tenaga pengajar dan anak didik menjadi "motor" penggerak utama kurikulum. Sedangkan alat-alat dan situasi pendidikan menjadi faktor pendukung untuk mencapai keberhasil dari pelaksanaann kurikulum (Lias Hasibuan, 2010: 21-22).

Oleh karena itu, besarnya peran kurikulum dalam pembelajaran hendaknya sebanding dengan pemahaman calon guru tentang kurikulum yang diterapkan di sekolah. Bagaimana pembelajaran dapat berjalan dengan lancar dan suasana yang menyenangkan atau bagaimana tujuan pembelajaran dapat tercapai dengan efektif dan efisien atau bagaimana materi ajar dapat diterima dengan baik oleh peserta didik bilamana calon guru tidak memahami dengan betul kurikulum yang diterapkan. 
Sebagai calon guru yang hari ini sangat dibutuhkan keprofesionalannya, menimbang mutu guru yang masih sesuai harapan yang tergambar dari hasil uji ompetensi guru (UKG) maka satu aspek penting yang harus benar-benar dikuasai sebelum turun ke dunia kerja adalah penguasan tentang kurikulum. Apa itu kurikulum, fungsinya dan bagaimana cara menerapkannya di lapangan. Tiga pertanyaan mendasar hendaknya mampu dipahami betul sehingga menghasilkan

PPL dituntut memahami secara menyeluruh seperti apa revisi kurikulum 2013 baik dari teorinya ataupun penerapannya di lapangan.

Terdapat empat pokok revisi kurikulum 2013, yakni (a) penataan kompetensi sikap spiritual dan sosial pada semua mata pelajaran (b) Koherensi KI-KD dan penyelarasan dokumen (c) Pemberian ruang kreatif kepada dalam mengimplementasikan kurikulum. (d) penataan kompetensi yang tidak dibatasi oleh pemenggalan taksonomi proses berpikir (Kementerian Pendidikan dan Kebudayaan: 2016: 6). kerja. Hari ini, calon guru atau mahasiswa

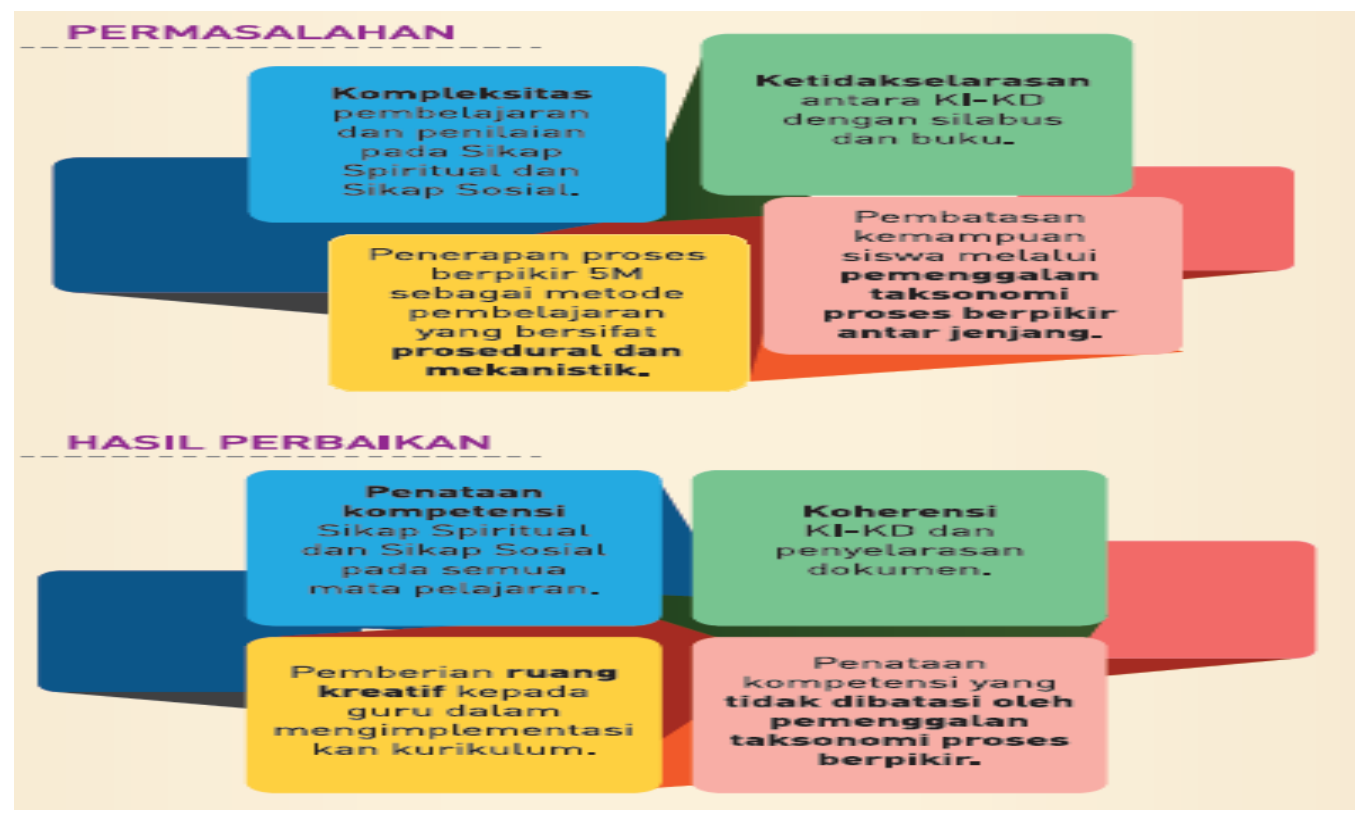

Gambar 1. Permasalahan dan Hasik Perbaikan

\section{Empat Pokok Revisi Kurikulum 2013}

Terlebih lagi, salah satu karakteristik utama dalam revisi kurikulum 2013 yakni guru yang profesional harus mampu menerapkan pembelajaran berbasis high order thingking skill. Guru diminta mampu mencetak peserta didik tidak hanya mengetahui apa yang diajarkan namun bisa mencipta sesuatu dari apa yang diajarkan.
Baik pada ranah kompetensi sikap, pengetahuan, dan keterampilan. Ketiga ranah kompetensi ini memiliki lintasan perolehan (proses psikologis) yang berbeda. Sikap diperoleh aktivitas menerima, menjalankan, menghargai, menghayati dan mengamalkan. Pengetahuan diperoleh melalui aktivitas mengingat, memahami, menerapkan, menganalisis, mengevaluasi dan mencipta. Keterampilan diperoleh 
melalui aktivitas mengamati, menanya, mencoba, menalar, menyaji, dan mencipta (Abidin, 2014, p. 13).

Logika sederhananya adalah guru diminta agar peserta bisa menciptakan sesuatu dari apa yang telah diajarkan, maka guru terlebih dahulu harus bisa mencipta sesuatu dari apa yang akan diajarkan kepada peserta didik. Maka kecakapan berpikir tingkat tinggi atau high order thingking skill (HOTS) henkdanya harus dimiliki guru sebelum dimiliki peserta didik. Maka tanpa pemahaman yang utuh oleh calon guru tentang karakteristik utama revisi kurikulum 2013 ini maka mustahil rasanya pembelajaran dapat berjalan optimal dan berhasil sebagaimana yang diekspektasikan.

Merujuk pada pokok-pokok pemikiran yang telah dijabarkan di atas, dapat dirumuskan hal utama yang dijabarkan dalam artikel ini adalah tingkat pemahaman calon guru terhadap revisi kurikulum 2013. Kemudian dikerecutkan menjadi tiga sub topik, yakni: Pertama, tingkat pemahaman calon guru terhadap perencanaan revisi kurikulum 2013. Kedua, tingkat pemahaman calon guru terhadap implementasi revisi kurikulum 2013. Ketiga, tingkat pemahaman calon guru terhadap evaluasi revisi kurikulum 2013. Keempat, tingkat pemahaman calon guru secara simultam (perencanaan, implementasi dan evaluasi) terhadap revisi kurikulum 2013.

\section{METODE PENELITIAN}

Artikel ini dituliskan dengan hasil olah dan analisis data kuantitatif. Pengumpulan data dilakukan dengan penyebaran angket. Sngket berupa tes untuk mengukur tingkat pemahaman calon guru terhadap revisi kurikulum 2013. Koresponden adalah mahasiswa praktek pengalaman lapangan dan mahasiswa tingkat akhir lembaga pendidikan dan tenaga kependidikan (LPTK). Angket dibuat menggunakan googleform dan disebarluaskan kepada koresponden melalui media sosial seperti whatsupp, dan
facebook.Sharing link angket googleform dilakukan kepada group whatsupp mahasiswa PPL ataupun ke pribadi lansung dimana penulis mengenal koresponden sedang mengikuti PPL atau sedang menjalani tingkat akhir strata 1.

\section{PEMBAHASAN}

\section{Tingkat Pemahaman Calon Guru terhadap Perencanaan Revisi Kurikulum 2013}

Perencanaan pembelajaran revisi kurikulum 2013 dirancang dalam bentuk silabus dan rencana pelaksanaan pembelajaran (RPP) yang mengacu pada Standar Isi. Perencanaan pembelajaran meliputi penyusunan rencana pelaksanaan pembelajaran dan penyiapan media dan sumber belajar serta perangkat penilaian pembelajaran dan skenario pembelajaran. Penyusunan silabus dan RPP disesuaikan dengan pendekatan pembelajaran yang digunakan (dalam Permendikbud No 22 tahun 2016) .

\section{Silabus}

Silabus merupakan acuan penyusunan kerangka pembelajaran untuk setiap bahan kajian mata pelajaran. Silabus dikembangkan berdasarkan Standar Kompetensi Lulusan dan Standar Isi untuk satuan pendidikan dasar dan menengah sesuai dengan pola pembelajaran pada setiap tahun ajaran tertentu. Silabus digunakan sebagai acuan dalam pengembangan rencana pelaksanaan pembelajaran. Silabus paling sedikit memuat: a) Identitas mata pelajaran (khusus SMP/MTs/SMPLB/Paket B dan SMA/MA/SMALB/SMK/MAK/Paket C/ Paket C Kejuruan); b) Identitas sekolah meliputi nama satuan pendidikan dan kelas; c) Kompetensi inti, merupakan gambaran secara kategorial mengenai kompetensi dalam aspek sikap, pengetahuan, dan keterampilan yang harus dipelajari peserta 
didik untuk suatu jenjang sekolah, kelas dan mata pelajaran; d) Kompetensi dasar, merupakan kemampuan spesifik yang mencakup sikap, pengetahuan, dan keterampilan yang terkait muatan atau mata pelajaran; e) Tema (khusus $\mathrm{SD} / \mathrm{MI} / \mathrm{SDLB} /$ Paket A); f) Materi pokok, memuat fakta, konsep, prinsip, dan prosedur yang relevan, dan ditulis dalam bentuk butir-butir sesuai dengan rumusan indikator pencapaian kompetensi; g) Pembelajaran, yaitu kegiatan yang dilakukan oleh pendidik dan peserta didik untuk mencapai kompetensi yang diharapkan; h) Penilaian, merupakan proses pengumpulan dan pengolahan informasi untuk menentukan pencapaian hasil belajar peserta didik; i) Alokasi waktu sesuai dengan jumlah jam pelajaran dalam struktur kurikulum untuk satu semester atau satu tahun; dan j) Sumber belajar, dapat berupa buku, media cetak dan elektronik, alam sekitar atau sumber belajar lain yang relevan.

\section{Rencana Pelaksanaan Pembelajaran}

Rencana Pelaksanaan Pembelajaran (RPP) adalah rencana kegiatan pembelajaran tatap muka untuk satu pertemuan atau lebih. RPP dikembangkan dari silabus untuk mengarahkan kegiatan pembelajaran peserta didik dalam upaya mencapai Kompetensi Dasar (KD). Setiap pendidik pada satuan pendidikan berkewajiban menyusun RPP secara lengkap dan sistematis agar pembelajaran berlangsung secara interaktif, inspiratif, menyenangkan, menantang, efisien, memotivasi peserta didik untuk berpartisipasi aktif, serta memberikan ruang yang cukup bagi prakarsa, kreativitas, dan kemandirian sesuai dengan bakat, minat, dan perkembangan fisik serta psikologis peserta didik. RPP disusun berdasarkan KD atau subtema yang dilaksanakan kali pertemuan atau lebih. Komponen RPP terdiri atas: a) Identitas sekolah yaitu nama satuan pendidikan; b) Identitas mata pelajaran atau tema/subtema; c) Kelas/semester; d) Materi pokok; e) Alokasi waktu ditentukan sesuai dengan keperluan untuk pencapaian $\mathrm{kd}$ dan beban belajar dengan mempertimbangkan jumlah jam pelajaran yang tersedia dalam silabus dan $\mathrm{kd}$ yang harus dicapai; f) Tujuan pembelajaran yang dirumuskan berdasarkan $\mathrm{kd}$, dengan menggunakan kata kerja operasional yang dapat diamati dan diukur, yang mencakup sikap, pengetahuan, dan keterampilan; g) Kompetensi dasar dan indikator pencapaian kompetensi; dan h) Materi pembelajaran, memuat fakta, konsep, prinsip, dan prosedur yang relevan, dan ditulis dalam bentuk butir-butir sesuai dengan rumusan indikator ketercapaian kompetensi (dalam permendikbud no 22 tahun 2016);

Hasil sebaran angket manyatakan bahwa tingkat pemahaman calon guru terhadap revisi kurikulum 2013 adalah sebesar 69,1\%. Angka ini didapat dari telaah jawaban yang dijawab dengan benar oleh koresponden. Dari total $100 \%$, koresponden yang menjawab soal angket dengan benar adalah 69,1 \%. Dengan demikian, koresponden yang memaha mi dengan benar tentang perencanaan revisi kurikulum 2013 adalah sebesar $69.1 \%$.

\section{Tingkat Pemahaman Calon Guru terhadap Implementasi Revisi Kurikulum 2013}

Merujuk pada Permendikbud No 22 tahun 2016 tentang Standar Proses Pendidikan Dasar dan Menengah, pelaksanaan pembelajaran merupakan implementasi dari RPP, meliputi kegiatan pendahuluan, inti dan penutup.

\section{Kegiatan Pendahuluan}

Dalam kegiatan pendahuluan, guru wajib: a) menyiapkan peserta didik secara psikis dan fisik untuk mengikuti proses pembelajaran; b) memberi motivasi belajar peserta didik secara kontekstual sesuai manfaat dan aplikasi materi ajar dalam kehidupan sehari-hari, dengan memberikan contoh dan perbandingan lokal, nasional 
dan internasional, serta disesuaikan dengan karakteristik dan jenjang peserta didik; c) mengajukan pertanyaan-pertanyaan yang mengaitkan pengetahuan sebelumnya dengan materi yang akan dipelajari; d) menjelaskan tujuan pembelajaran atau kompetensi dasar yang akan dicapai; dan e) menyampaikan cakupan materi dan penjelasan uraian kegiatan sesuai silabus.

\section{Kegiatan Inti}

Kegiatan inti menggunakan model pembelajaran, metode pembelajaran, media pembelajaran, dan sumber belajar yang disesuaikan dengan karakteristik peserta didik dan mata pelajaran. Pemilihan pendekatan tematik dan /atau tematik terpadu dan/atau saintifik dan/atau inkuiri dan penyingkapan (discovery) dan/atau pembelajaran yang menghasilkan karya berbasis pemecahan masalah (project based learning) disesuaikan dengan karakteristik kompetensi dan jenjang pendidikan.

\section{Sikap}

Sesuai dengan karakteristik sikap, maka salah satu alternatif yang dipilih adalah proses afeksi mulai dari menerima, menjalankan, menghargai, menghayati, hingga mengamalkan. Seluruh aktivitas pembelajaran berorientasi pada tahapan kompetensi yang mendorong peserta didik untuk melakuan aktivitas tersebut.

\section{Pengetahuan}

Pengetahuan dimiliki melalui aktivitas mengetahui, memahami, menerapkan, menganalisis, mengevaluasi, hingga mencipta. Karakteritik aktivititas belajar dalam domain pengetahuan ini memiliki perbedaan dan kesamaan dengan aktivitas belajar dalam domain keterampilan. Untuk memperkuat pendekatan saintifik, tematik terpadu, dan tematik sangat disarankan untuk menerapkan belajar berbasis penyingkapan/penelitian (discovery/inquiry learning). Untuk mendorong peserta didik menghasilkan karya kreatif dan kontekstual, baik individual maupun kelompok, disarankan yang menghasilkan karya berbasis pemecahan masalah (project based learning).

\section{Keterampilan}

Keterampilan diperoleh melalui kegiatan mengamati, menanya, mencoba, menalar, menyaji, dan mencipta. Seluruh isi materi (topik dan sub topik) mata pelajaran yang diturunkan dari keterampilan harus mendorong peserta didik untuk melakukan proses pengamatan hingga penciptaan. Untuk mewujudkan keterampilan tersebut perlu melakukan pembelajaran yang menerapkan modus belajar berbasis penyingkapan/penelitian (discovery/inquiry learning) dan pembelajaran yang menghasilkan karya berbasis pemecahan masalah (project based learning).

\section{Kegiatan Penutup}

Dalam kegiatan penutup, guru bersama peserta didik baik secara individual maupun kelompok melakukan refleksi untuk mengevaluasi: a) seluruh rangkaian aktivitas pembelajaran dan hasil-hasil yang diperoleh untuk selanjutnya secara bersama menemukan manfaat langsung maupun tidak langsung dari hasil pembelajaran yang telah berlangsung; b) memberikan umpan balik terhadap proses dan hasil pembelajaran; c) melakukan kegiatan tindak lanjut dalam bentuk pemberian tugas, baik tugas individual maupun kelompok; dan d) menginformasikan rencana kegiatan pembelajaran untuk pertemuan berikutnya (dalam Permendikbud No 22 tahun 2016).

Hasil sebaran angket mengungkapkan bahwa tingkat pemahaman calon guru terhadap implementasi revisi kurikulum 2013 adalah sebesar 57.5\%. Angka ini didapat dari telaah jawaban yang dijawab dengan benar oleh koresponden. 
Dari total $100 \%$, koresponden yang menjawab soal angket dengan benar adalah $57.5 \%$. Dengan demikian, koresponden yang memahami dengan benar tentang implementasi revisi kurikulum 2013 adalah sebesar $57.5 \%$.

\section{Tingkat Pemahaman Calon Guru terhadap Evaluasi Revisi Kurikulum 2013}

Penilaian proses pembelajaran menggunakan pendekatan penilaian otentik (authentic assesment) yang menilai kesiapan peserta didik, proses, dan hasil belajar secara utuh. Keterpaduan penilaian ketiga komponen tersebut akan menggambarkan kapasitas, gaya, dan perolehan belajar peserta didik yang mampu menghasilkan dampak instruksional (instructional effect) pada aspek pengetahuan dan dampak pengiring (nurturant effect) pada aspek sikap.

Hasil penilaian otentik digunakan guru untuk merencanakan program perbaikan (remedial) pembelajaran, pengayaan (enrichment), atau pelayanan konseling. Selain itu, hasil penilaian otentik digunakan sebagai bahan untuk memperbaiki proses pembelajaran sesuai dengan Standar Penilaian Pendidikan. Evaluasi proses pembelajaran dilakukan saat proses pembelajaran dengan menggunakan alat: lembar pengamatan, angket sebaya, rekaman, catatan anekdot, dan refleksi. Evaluasi hasil pembelajaran dilakukan saat proses pembelajaran dan di akhir satuan pelajaran dengan menggunakan metode dan alat: tes lisan/perbuatan, dan tes tulis. Hasil evaluasi akhir diperoleh dari gabungan evaluasi proses dan evaluasi hasil pembelajaran (dalam Permendikbud No 22 tahun 2016). Maka penjelasan lebih lanjut dijelaskan lebih detail pada Permendikbud No 23 tahun 2016 tentang Standar Penilaian Pendidikan Dasar dan Menengah.

$$
\text { Hasil sebaran angket }
$$

mengungkapkan bahwa tingkat pemahaman calon guru terhadap evaluasi revisi kurikulum 2013 adalah sebesar 13.6\%.
Angka ini didapat dari telaah jawaban yang dijawab dengan benar oleh koresponden. Dari total $100 \%$, koresponden yang menjawab soal angket dengan benar adalah $13.6 \%$. Dengan demikian, koresponden yang memahami dengan benar tentang evaluasi revisi kurikulum 2013 adalah sebesar $13.6 \%$.

\section{Tingkat Pemahaman Calon Guru terhadap Evaluasi Revisi Kurikulum 2013}

Secara keseluruhan, didapatkan bahwa tingkat pemahaman calon guru terhadap revisi kurikulum 2013 meliputi pemahaman perencanaan, implementasi dan evaluasi adalah sebesar 49,6\%.Dari total $100 \%$, koresponden yang menjawab soal angket dengan benar adalah $13.6 \%$. Dengan demikian, koresponden yang memahami dengan benar tentang secara utuh tentang revisi kurikulum 2013 adalah sebesar $49.6 \%$. Angka ini yang kecil ini menunjukkan tingkat pemahaman calon guru terhadap kurikulum yang diterapkan masih rendah. Calon guru dinilai tidak betul-betul paham terhadap kurikulum sehingga wajar saja bilamana proses pembelajaran tidak berjalan lancar. Ataupun tujuan pembelajaran tidak dapat dicapai sebagaimana yang diharapkan. Maka dengan ini, artikel ini dapat menjadi rekomendasi bagi LPTK untuk bagaimana caranya agar calon guru betul-betul memahami kurikulum sebelum terjun ke dunia kerja. Hal ini perlu segera menjadi perhatian LPTK dalam rangka membangkitkan mutu guru yang beberapa tahun terakhir terpuruk.

\section{KESIMPULAN}

Bertitik tolak dari penjabaran dasr pemikiran, kajian teori serta data hasil penelitian yang telah dijabarakan maka dapat disimpulkan sebagai berikut: 1) Tingkat pemahaman calon guru terhadap revisi kurikulum 2013 adalah sebesar 69,1 $\%$; 2) Tingkat pemahaman calon guru 
terhadap implementasi revisi kurikulum 2013 adalah sebesar $57.5 \%$; 3) Tingkat pemahaman calon guru terhadap evaluasi revisi kurikulum 2013 adalah sebesar 13.6 $\%$; dan 4) Tingkat pemahaman calon guru terhadap revisi kurikulum 2013 meliputi pemahaman perencanaan, implementasi dan evaluasi adalah sebesar 49,6\%.

\section{DAFTAR PUSTAKA}

Abidin, Y. (2014). Desain Sistem Pembelajaran Dalam Konteks Kurikulum 2013. Bandung: PT. Refika Aditama.

Anonim. (2016). Buku Pedoman Pelaksanaan Praktek Pengalaman Lapangan. Bandung: Universitas Pendidikan Indonesia.

Anonim. (2011). Buku Panduan Pengajaran Mikro UNY. Yogyakarta : Universitas Negeri Yogyakarta.

Biro Komunikasi dan Layanan Masyarakat Kemdikbud. (2016). Majalab Jendela Pendidikan dan Kebudayaan: Empat Pilar Kurikulum 2013. Jakarta: Kemdikbud.

Direktorat Jenderal Pendidikan Tinggi Kementerian Pendidikan Nasional Republik Indonesia. (2007). Bu ku Pedoman Kerangka Kualifikasi Nasional Indonesia Edisi 1. Jakarta

Hasibuan, J.J. dan Moedjiono. (2009). Proses Belajar Mengajar. Bandung: Remaja Rosdakarya.

Hasibuan, Lias. (2010). Kurikulum dan Pemikiran Pendidikan. Jakarta: Gaung Persada.

Hamalik, Oemar. (2009). Pendidikan Guru Berdasarkan Kompetensi. Jakarta: Bumi Aksara

Rochman, Natawidjaja. (1983). Pendidikan Guru Berdasarkan Kompetensi. Bandung: Fakultas Pasca Sarjana IKIP Bandung.

Sardiman. (2005). Interaksi dan Motivasi Belajar Mengajar. Jakarta: Raja Grafindo Persada.
Syaodih, Nana. (2010). Pengembangan Kurikulum; Teori dan Praktik. Bandung : PT. Remaja Rosdakarya.

Suharsaputra, Uhar. (2015). Manajemen Pendidikan Perguruan Tinggi. Bandung: Refika Aditama.

Sukirman, Dadang. (2012). Pembelajaran Micro Teaching. Jakarta: Direktorat Jenderal Pendidikan Islam Kementerian Agama.

Permendikbud No 22 tahun 2016 tentang Standar Proses Pendidikan Dasar dan Menengah.

Permendikbud No 23 tahun 2016 tentang Standar Penilaian Pendidikan Dasar dan Menengah. 